\title{
Evaluation on the Application of GLB Structures
}

\author{
Guosong Yang ${ }^{*}$, Kun Wang ${ }^{2}$ \\ ${ }^{1}$ Beijing Yanhuang International Engineering Design Co., Ltd., Nanjing, China \\ ${ }^{2}$ College of Civil Engineering, Yangzhou University, Yangzhou, China \\ Email: *yanggs2019@163.com, wangkun@yzu.edu.cn
}

How to cite this paper: Yang, G.S. and Wang, K. (2020) Evaluation on the Application of GLB Structures. Journal of Materials Science and Chemical Engineering, 8, 21-37.

https://doi.org/10.4236/msce.2020.85003

Received: April 6, 2020

Accepted: May 22, 2020

Published: May 25, 2020

Copyright $\odot 2020$ by author(s) and Scientific Research Publishing Inc. This work is licensed under the Creative Commons Attribution International License (CC BY 4.0).

http://creativecommons.org/licenses/by/4.0/

(c) (i) Open Access

\begin{abstract}
Glued Laminated Bamboo (GLB) is one kind of composite material; the use of GLB in structural engineering can reduce the demand for wood, a possible solution to relieve the damage to natural forest. With the help of the design and construction experience of timber structures, a new type of building structure: bamboo structure is introduced. This paper presents a comprehensive review on the study of GLB and bamboo structure. Some important physical, mechanical, and chemical properties such as seismic performance, fire resistance, and energy consumption are discussed. In addition, the property of bamboo composites, the failure mode of GLB beam and columns are also analyzed. This paper also pointed out the problems faced by the development of bamboo structure, which can be a suggestion for subsequent research. In general, GLB is a green and environmentally-friendly structural material and the development of bamboo structure provides another choice to conform the concept of sustainable development.
\end{abstract}

\section{Keywords}

Glued Laminated Bamboo, Bamboo Structure, Seismic Performance, Energy Consumption, Bamboo Composites

\section{Introduction}

Bamboo is almost accompanied by the history of the entire human society. Since green and sustainable development has become the theme of the current era, bamboo has gained popularity in the building structure market [1]. With a shorter growth cycle than wood, bamboo has a strong regenerate ability [2] [3]. Study shows that both the compression and tension strength of bamboo parallel to fibers are higher than that of wood, and it is more suitable to be used as structural material [4]. Round bamboo structure was designed and built thousands of years ago and continues the $21^{\text {st }}$ century [5]. However, the hollow thin-walled 
structure of bamboo limits the development of bamboo structure for a long time [6]. Correspondingly, timber structures have been widely used, and even today, there are still a large number of wooden houses in Japan and North America. After the industrial revolution, new types of building materials such as cement and steel quickly occupied the construction market, which makes bamboo become an auxiliary material in building constructions, such as building formwork, slope treatment, scaffold and decoration material [7].

Due to the light weight and high axial strength of bamboo, the attempt to apply bamboo in building structures has never stopped. In order to overcome the defects of natural round bamboo, Glued Laminated Bamboo (GLB), a kind of composite material was introduced. According to the different production methods, GLB can be subdivided into three types: parallel strand bamboo (PSB) [8]; laminated bamboo lumber (LBL) [9] and Glubam [10]. Similar to wood, the plasticity of bamboo is high than that of concrete; GLB can be fabricated into any cross-sectional size according to requirements, which greatly improves the practicality and competitiveness of bamboo in building structures. At present, bamboo structures can be designed and built like traditional buildings, as it is called bamboo structures. Bamboo structure system is based on modern mechanics, materials science, structural design and experimental theory. It is a new type of structural system with the help of the development of new bamboo structural materials, the establishment of industrial production methods, the use of modern structural design, construction methods and maintenance techniques to splicing and installing bamboo components [11] [12].

The use of GLB in building structures is a gradual process; it was firstly applied in composites such as bamboo-steel composites [13] and bamboo-concrete composite [14] to reduce mass while maintaining bearing capacity. In recent years, GLB structures have emerged in reference of the design experience of timber structure, including Glubam bridge [15], bamboo frame structure house made of LBL [16]) and prefabricated bamboo house [17].

Based on the existing research results of GLB and the design and construction experience of timber structure, through investigations and tests, the authors get further analyzed the potential of using GLB as structural materials. It can be concluded that GLB is a green building material that can be produced on large scale.

\section{Advantages of Developing Bamboo Structures}

\subsection{The Design and Construction Experience of Timber Structures}

Wood is the main building material for thousands of years before the industrial revolution, and variety types of timber structures were developed. Large numbers of timber structures in North America, Japan and China offer rich design and construction experience. At present, a complete design, construction and maintenance system have established for timber structures, and many countries 
and regions have their own design specifications such as: the National Design Specification of the USA [18], China design code for timber structure [19] and Eurocode 5 Design of wooden structures [20]. There are great similarities between GLB and wood, both wood fiber and bamboo fiber are high molecular polymeric sugar, and the axially layered distribution of bamboo fibers make its bearing capacity parallel to fiber even higher than that of wood [21]. With the help of new manufacturing process, the dimensions of GLB components can be obtained consistently with wood. Thus, the design and construction method of timber structures can be a good reference for bamboo structures. Since the continuity of bamboo fiber is better than that of wood, theoretically, bamboo is more suitable as a structural material in construction market.

\subsection{The Richness of Bamboo Resources}

There are 1250 different species of bamboo cover the land of over 26 million $\mathrm{hm}^{2}$ in the world, Asia accounts for about 1000 species, covering an area of over 18 million $\mathrm{hm}^{2}$ and the rest are mainly distributed in America and Africa, as shown in Figure 1 [22]. Due to the fast-growing characteristic of bamboo, regeneration can be completed in 3 - 5 years, which provides a stable supply of bamboo resources.

\subsection{Low Environmental Load and Application Cost}

The environmental impacts of human activities mainly include climate change caused by carbon emissions and the destruction of natural environment caused by different types of wastes. In addition, the dependence on fossil energy hinders the sustainable development of human society. GLB is a composite material based on natural materials; the growth of bamboo is a carbon sequestration process. The carbon emission of GLB is still kept at a low level even if the transportation and production process are included. Moreover, the energy consumption of GLB in production process is much lower than that of steel and cement, Table 1 displaces the environment load of several common building materials [10]. Study shows that construction waste account for $40 \%$ of wastes in China or 1.5 billion tons a year [23], most of which cannot be reused. On contrast, the remains of bamboo structure after been demolished can also be used again, such as construction formwork and decoration materials [4] [22]. This is undoubtedly a good way to reduce construction waste in most developing countries. It is worth noting that the cost and carbon emission of the entire life cycle of bamboo structure is comparable to that of timber structure, but significantly lower than that of the reinforced concrete structure [24]. This is one of the reasons that Japan and North America still build a large number of wooden houses.

\subsection{Mechanical Properties of GLB}

Many factors influence the performance of GLB. Test studies reveal that the properties of raw bamboo and the gluing property of the bonding surface are two main factors [25] [26]. A moisture content of $10 \%$ is considered to be the 


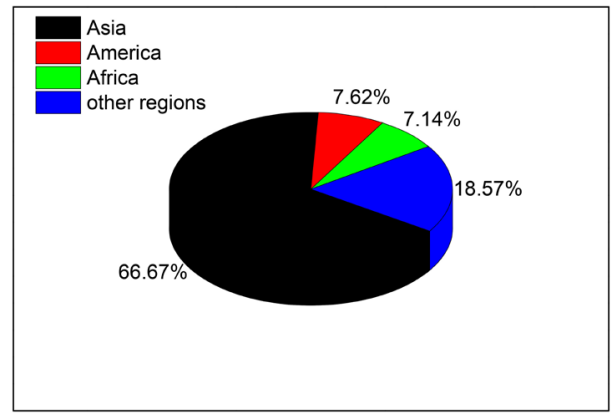

Figure 1. Distribution of world bamboo resource.

Table 1. Environmental load of GLB and other kinds of building materials.

\begin{tabular}{ccc}
\hline Material & Carbon emission $\left(\mathrm{kg} / \mathrm{m}^{3}\right)$ & Energy consumption $\left(\mathrm{GJ} / \mathrm{m}^{3}\right)$ \\
\hline GLB & -261 & 2.7 \\
Engineered wood & -168 & 4.5 \\
Cement & 2040 & 11 \\
STEEL & 8117 & 448 \\
\hline
\end{tabular}

Note: The environmental load of GLB is the accurate data of Glubam, since the production process of the three different types of GLB are of high level of similarity, the data of Glubam is used as an overall indicator of GLB.

best condition for GLB to exhibit its mechanical properties [27] and the compression and tension strength of GLB increase with the increase of the fiber density [28]. Askarinejad discovered that for round bamboo, the fiber density decreased from the outer radial diameter [29]. Through the improvement of hot-pressing technics, the influence of gluing property can be neglected [27]. In general, GLB well inherits the mechanical properties of raw bamboo. Three types of GLB making with different processes are introduced according to different needs.

\subsubsection{Parallel Strand Bamboo (PSB)}

PSB is produced by decompose the original bamboo along the fibers into small units and then glue them together through high pressure [8]. In his method, the distribution of bamboo fibers is uniform and compact, which significantly improve the tension and compressive strength.

\subsubsection{Laminated Bamboo Lumber (LBL)}

In the process of producing LBL, raw bamboo is firstly processed into bamboo strips with a rectangular cross section. LBL is obtained with the bamboo strips glued together after smearing a layer of adhesive on the surface. Figure 2 shows the fiber arrangement of LBL [27]. LBL uses less adhesive and the production process is simple, so it is more economical.

\subsubsection{Glubam}

Glubam differs from the other two types of GLB in the orthogonal distribution of bamboo fibers. If a coordinator system is established with $\mathrm{x}$ axis represents the 
main fiber direction (longitudinal grains direction), y axis represents the less-fiber direction (transverse grains direction), $\mathrm{z}$ axis represents the thickness or glue surface direction, as shown in Figure 3. The ratio of longitudinal grains and transverse grains is typically $4: 1$ [10]. It was introduced to maintain good performance even if it is under complex stress conditions.

The mechanical properties of GLB parallel to fiber direction are summaries in Table 2, the mechanical properties of fir and steel are also included [8] [27] [30] [31]. As referred above, there are differences in mechanical properties of GLB with different making processes. In design progress, the corresponding types can be chosen according to need.

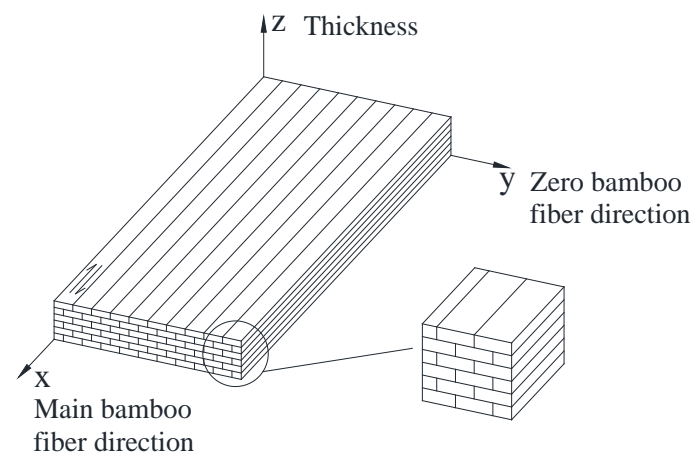

Figure 2. The arrangement of bamboo grain in LBL.

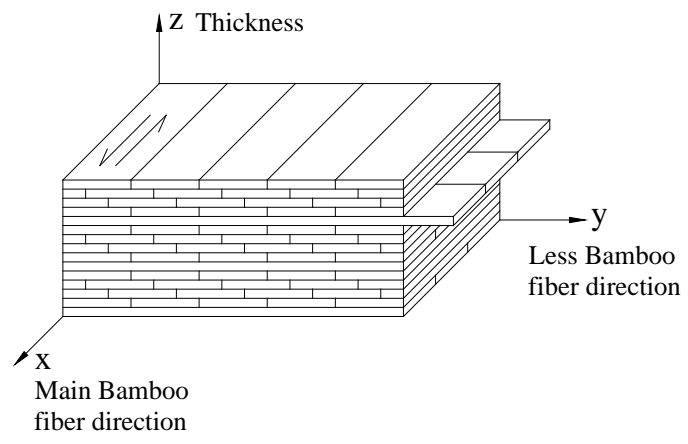

Figure 3. The arrangement of bamboo grain in Glubam.

Table 2. Mechanical properties of GLB, fir and steel.

\begin{tabular}{cccccc}
\hline Material & $\begin{array}{c}\text { Compression } \\
\text { strength (MPa) }\end{array}$ & $\begin{array}{c}\text { Tension strength } \\
(\mathrm{MPa})\end{array}$ & $\begin{array}{c}\text { Shear strength } \\
(\mathrm{MPa})\end{array}$ & $\begin{array}{c}\text { Bending strength } \\
(\mathrm{MPa})\end{array}$ & MOE (GPa) \\
\hline PSB & 129 & 248 & 15 & 119 & 25 \\
LBL & 73 & 85 & 17 & 115 & 15 \\
Glubam & 51 & 83 & 16 & 99 & 9.4 \\
Fir & 57 & 49 & 11 & 68 & 13 \\
Steel & $250-400$ & $250-400$ & - & $235-400$ & $190-210$ \\
\hline
\end{tabular}

Note: The values for GLB and fir are the results parallel to the fiber direction. 


\section{Glued Laminated Bamboo Composite Structures}

At present, composite structure is the main form of GLB as a structural material applied in building structures.

\subsection{GLB-Wood Composites}

The tension and compression strength of GLB are much higher than that of wood. Therefore, GLB is usually used as a reinforcement material in bamboo-wood composites [32] [33]. Taking bending members as an example, the arrangement of bamboo reinforcements in tension zone can effectively increase the height of the compression zone, thereby improving the bearing capacity of the bending member as a whole. On the other hand, the coordination of deformation between GLB and wood also enhances the workability of GLB-wood composites.

\subsection{Bamboo-Steel Composites}

Bamboo-steel composites use the lightweight characteristics of bamboo to reduce the mass of structure itself [34], since the compressive strength of GLB is $25 \%$ of steel, but the density is only $10 \%$ of it [9]. Compared with bamboo, the surface of steel is smoother, thus obtaining a reliable connection property between steel and bamboo is of great significance. Pure adhesive connection and self-tapping screw enhanced adhesive connection are two widely used forms [35]. For pure adhesive connection, the shear strength of the interface is low, only 1.64 MPa, and the anti-sliding ability is weak when subjected to shear load [35] [36]. On the other hand, self-tapping screw reinforcement can significantly improve the shear strength of the interface. In this way, the integrity and bearing capacity of the component is improved.

\subsection{Bamboo Reinforced Concrete (BRC)}

Obviously, BRC is developed on the basis of steel reinforced concrete (SRC). In the ages faced with great shortage of steel, BRC beams introduced by using raw bamboo instead of steel have been used in buildings [37] [38] [39] [40]. In the 1980s, an evaluation of bamboo strip-concrete slabs was conducted after the slabs had been put into use for 27 years. After a series of anatomical tests, a conclusion was made that BRC is not suitable to be load-bearing members [41]. The factors account for the conclusion are: 1) the poor bonding property between bamboo and concrete [42], 2) bamboo strips become hard and brittle after year in the concrete, 3 ) growth defects and variability in distribution of bamboo fiber make raw bamboo not suitable for applying directly in concrete [43]. With the advancement of materials science, the physical and mechanical properties of GLB made from new processes have been greatly improved compared with raw bamboo.

\subsubsection{Study of Bending Property and Bond Behavior}

Ghavami studied the bending capacity of bamboo reinforced Lightweight con- 
crete beams, and concluded that compared with plain concrete beam; the ultimate applied load was increased up to $400 \%$ [44]. He also suggested that the $3 \%$ bamboo, in relation to the concrete section, is the recommended value. Teral compared the damage characteristics of BRC beam and SRC beam, and discovered that the cracking patterns in BRC beams were similar to that of SRC beams [45]. As a result, the fracture behavior of BRC beam can be evaluated by the existing formula of SRC beam.

Since BRC beams work the same way as reinforced concrete beams, so the main factors which affect the bonding property between steel reinforced bar and concrete also influence the bonding property of BRC. Study shows that Negrolin-sand-wire treatment can improve the bond property of the interface and experimental study shows that the bamboo-concrete bonding strength increased by $90 \%$ [46]. Moreover, the dimensional changes of bamboo due to moisture variations are more apparently than the influence of temperature. Thus, impermeability treatment of bamboo is also a good way to keep the bonding strength [46]. In addition, using the good plasticity of GLB, the cutting of the notch or the thread on the surface of the ribs can enhance mechanical bond between GLB and concrete and also reduce the influence expansion or shrinkage caused by the change of moisture and temperature [47]. Archila also pointed out that chemical adhesion can be easily overcome and strengthening the mechanical connection between bamboo reinforcement and concrete is the key to improve the bonding property [29].

\subsubsection{Study of Durability}

As a natural composite material, cyclic changes in temperature and humidity are the main factors affecting the life-span of GLB, bamboo with low moisture especially when humidity content is less than $15 \%$ is less prone to mold [46]. Studies have shown that GLB achieves optimum performance with the moisture content of $10 \%$ [47]. In order to keep the moisture content of GLB stable, it is necessary to undergo an antiseptic treatment. The impregnation and surface coating are the two main treatment methods; the former is impregnated of raw bamboo (pre-treatment) [48], while the latter is coated with a layer of waterproof material on the surface of GLB (post-treatment) [49]. Usually, the durability of GLB has been significantly improved after anti-corrosion treatment while its mechanical properties keep stable. Although the anti-corrosion organic materials do not reduce the mechanical properties of GLB, for method of post-treatment, the loss of anti-corrosion material will at a faster rate, so it does not suitable for permanent structures.

\subsection{The Significance of Developing GLB Composite Structure}

At present, it is necessary to develop GLB composite structure especially bamboo reinforced concrete. Firstly, the use of GLB meets the concept of green and sustainable development while reducing the need for fossil resources and energy. On the other hand, with the rapid growth of world population and a fast rate of 
urbanization, the development of human society still faces the problem of steel shortage. According to the data released by the World Bank in 2019, the top ten countries and regions account for more than $90 \%$ of the world's total steel production, while the population of these place account for only 55\% total of the world. The distribution of world steel production in 2018 is displaced in Figure 4. It's worth noting that the steel output in China is more than half of the world's total, the author's investigation shows there are still many poor people living in adobe houses. Apart from steel, the use of GLB can effectively alleviate the contradiction between supply and demand in many developing countries.

\section{Bamboo Structures}

From the design experience of timber structures, it is completely feasible to design and construct bamboo buildings with 1 - 2 floors. Since there is no relevant design specification, the promotion of bamboo structure in commercial market has no legitimacy, which is also the main reason limiting the development of bamboo structure. Despite this, some GLB structures for academic research have been built in China recently.

\subsection{Bamboo Bridge}

The bamboo bridge is a simple structural form bamboo structure, the bamboo beam is the only load-bearing members. Relying on the piers on the two sides, the beam can obtain effective anchoring and lateral support, so it has good stability. For bridges with simple beam-slab system, strength and stiffness are the main indicators to be considered. Round bamboo bridge is only suitable for landscape design, while GLB-based bamboo beam expands the application range of the bamboo bridge. In 2008, based on Glubam, a bamboo pedestrian bridge was built in Hunan University [50]. Later Xiao designed the world's first bamboo bridge, which can be used for vehicles, and test results show that the mid-span deflection is less than the relevant regulations and meets the design requirements [51].

\subsection{Bamboo Frame Structure}

The frame structure is composed of beams and columns to hold the entire load of the building, the walls and roofs are the building envelopes.

The stress-strain curve of GLB under axial load is shown in Figure 5 [27], it can be concluded that the tensile load-stress curve is linear, while the compressive load-strain curve has a distinct linear stage and a nonlinear strengthening stage. Unlike steel, GLB has no yield stage when subjected to tension strength, and the fracture of bamboo fiber is instantaneous and irreversible. This is verified by the bending test results of GLB beam, Figure 6 displaces the typical load-displacement curve of GLB beam [27] [52]. This feature of GLB is disadvantageous for building structures and requires some safety redundancy during design process. To solve this problem, the bearing capacity design value of Glubam was reduced by using the allowable stress method [10]. 


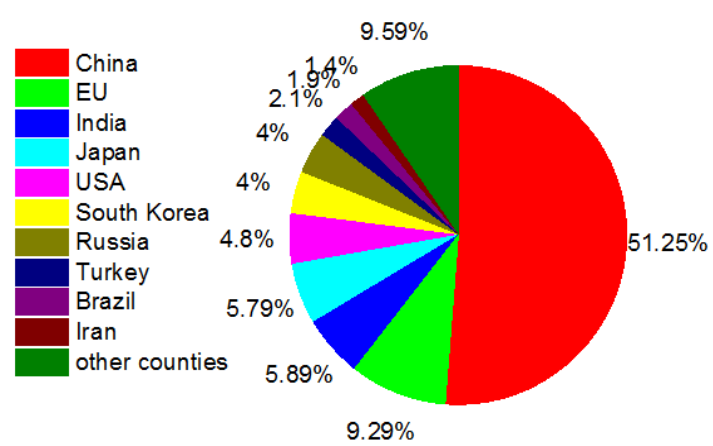

Figure 4. World steel production in 2018.

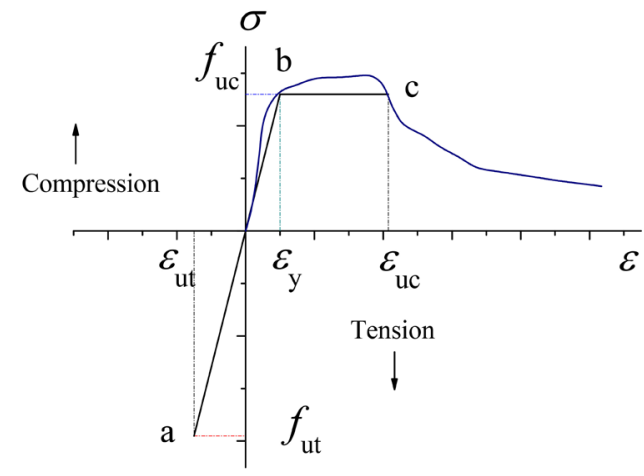

Figure 5. Axial stress-strain curve of GLB.

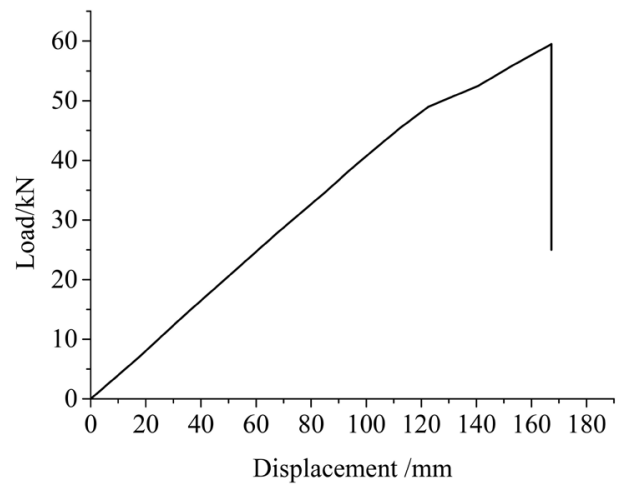

Figure 6. Typical load-displacement curve of GLB beam.

Experimental study on Glubam column under axial compression load shows that the long column failure is mainly controlled by stability, while the short column failure is mainly controlled by strength, and when the slenderness ratio of GLB column is less than 40, it can be considered as a short column [53]. Therefore, the failure mode of short column is suitable for the frame columns in the bamboo structure houses.

The low strength of the round bamboo node was one of the main factors restricting the development of bamboo structure since node is the key to maintaining integrity of building structures. Mortise-Tenon connection is the wisdom of ancient Chinese architects of timber structures. In this method, the compo- 
nents were connected together by precise hand-carving without the aid of other auxiliary materials. However, this method is inefficient in production and cannot achieve mass production in large scale [54]. Bolted joints are widely used in timber structures. Experimental studies showed that the method of bolt connection suggested by timber structure specification can be a reference for the connection design of bamboo structure [16].

\subsection{Prefabricated Bamboo Structure}

Prefabricated bamboo structure has the advantages of light in weight, low in cost and simple in construction. The prefabricated bamboo structure is simple in form, and is suitable for disaster relief operations or using as temporary constructions [55], and the GLB components can be completely reused after the building is demolished.

\section{Evaluation of Bamboo Structures}

\subsection{Seismic Performance}

Earthquake has brought huge losses to human society. The 2008 Wenchuan earthquake in China, the Haiti earthquake in 2010, and the eastern Japan earthquake in 2011 have caused tens of thousands of deaths. Seismic resistance research of building structures is a topic that structural engineers must face. Earthquake resistance of building structures can be divided into two parts: improving the seismic capacity of buildings; finding ways to reduce the loss caused by earthquake. Obviously, the former puts forward higher requirements on the structural form of buildings, material strength and construction level, which greatly increases the construction cost. The latter is to achieve the seismic purposes from the perspective of avoiding earthquakes, which is obviously more economical [56] [57]. The timber structures in Japan are typical examples for avoiding earthquakes, and this method proved to be very effective.

Bamboo structure adopts the same seismic method as timber structures as bamboo structures are usually short, so they will not amplify the force caused by earthquake, when the intensity of earthquake is low, serious damage happens to bamboo structures can be avoided [11]. In addition, due to the lightweight character of the bamboo, even if it collapses during earthquake, it generally will not cause fatal injuries.

\subsection{Fire Resistance}

Once being on fire, the destruction of bamboo or timber structures is devastating. The fire that took place in the National Museum of Brazil in 2018 led to the complete destruction of the former royal palace of Portugal, in which $90 \%$ of the artifacts (more than 20 million pieces) were destroyed, and in 2019, the wooden spire of Notre Dame Cathedral was also destroyed by fire.

GLB is a flammable material, after anti-corrosion treatment with anti-corrosion material containing grease, once the fire ignites the GLB structure, it will spread 
quickly. In order to reduce the possibility of catching fire in bamboo structures, usually, a layer of fireproof material is wrapped on the surface of GLB [58]. Fire-resistance test shows that compared to lightweight steel prefabricated house, prefabricated bamboo house has longer fire resistance time [17]. In addition, using gypsum boards and rock wool insulation can effectively prevent the spread of fire [59].

\subsection{Thermal Performance and Comfort}

The design of the bamboo structure has taken into account its thermal performance. The inside surface of the GLB walls are usually covered with a layer of gypsum board, with rock wool filled in the middle, and a layer of waterproof mortar coated on the surface of outside walls. Fire resistance test shows that when the inner temperature increases to $500^{\circ} \mathrm{C}$ and last for 30 minutes, the temperature of the outside wall is no more than $90^{\circ} \mathrm{C}$, as seen in Figure 7 [59]. Wang discovered that the thermal conductivity of bamboo-based walls is only slightly higher than that of wood-based [60]. In the cold reigns, bamboo structure can save $65 \%$ energy consumption compared with traditional concrete structures [61].

It is well known that natural bamboo does not cause any harm to the human body. For GLB, the production process will neither increase the harmful substances in a large amount. Experiments show that, before the fire resistance treatment, the concentration of harmful substances in the air of bamboo structure room is at a low level, and meets the standard of indoor air quality [62]. It can be concluded that bamboo structure is environmentally friendly and livable.

\subsection{The Dilemma Faced by the Development of Bamboo Structures}

The Application of GLB in building structures does give us a new visual and residential experience. However, the development of bamboo structures still needs to overcome a series of difficulties.

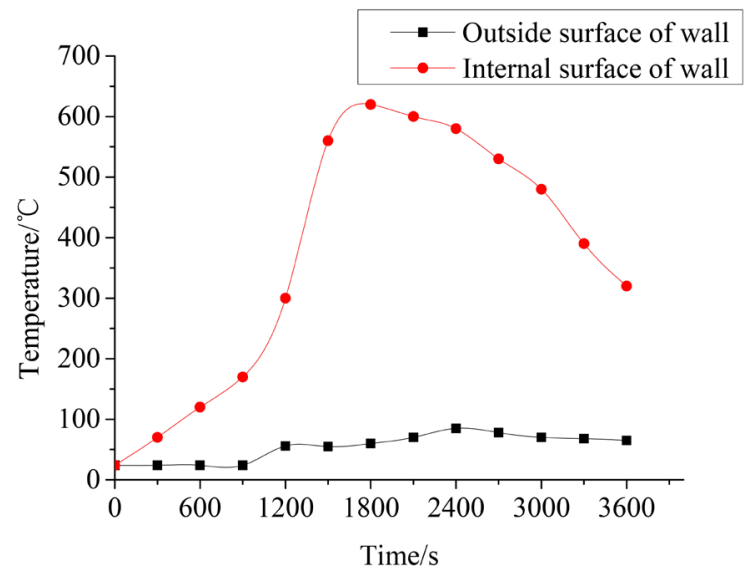

Figure 7. Temperature-time histories of GLB wall. 


\subsubsection{The Efficiency of Land Use}

The mechanical properties of natural materials used in building structures is significantly lower than that of traditional building materials such as steel and concrete. This significantly restricts the height of timber of bamboo structures, if a large number of such buildings are constructed, a large amount of land resources will be occupied for developing countries that are in the process of urbanization. On the other hand, most of the developing countries are facing the problem of rapid population growth, and a large amount of arable land is needed to ensure food supply while urban construction is in progress. The development of high-rise bamboo structures requires full reference to the construction experience of high-rise timber structures. China still retains a large number of ancient wooden towers, and the Yingxian Wooden Tower is the highest-preserved wooden structure with a height of more than 65 meters. The tower provides a basis for the development of high-rise bamboo and timber structures, but the tenon-and-mortise connection used in construction process does not meet the requirements of modern industrial production. On contrast, the Brock Commons Tallwood House, an 18-story student apartment with a total height of 53 meters, was completed in 2017 by the University of British Columbia (UBC) in Canada, and it has more reference value for high-rise bamboo structures.

\subsubsection{Lack of Bamboo Structure Design Code}

The lack of design specifications is the major obstacle for the development of bamboo structures. Moreover, GLB is mainly used for decorative materials at present, which leads manufacturers to pay more attention to the appearance quality while ignoring its mechanical strength. Therefore, the production of GLUED GLB is random, and its mechanical properties are also highly discrete. Only the establishment of a group and standard social production with the necessary quality testing procedures can pave the way for the use of GLB in construction market.

\section{Concluding Remarks}

There is a high potential for GLB applying in construction market to maximize economic and environmental benefits. Based on the development experience of timber structure, this paper evaluates the physical and mechanical properties of GLB and the prospect of bamboo structure. The following conclusions are summarized from this study:

- GLB is one kind of composite material with excellent mechanical properties. It is also a green natural material with low energy consumption and low pollution during the production process. Most importantly, GLB overcomes the shortcomings of the hollow structure of natural bamboo and this offers structural engineers a new choice in the design of building structures.

- GLB can be widely applied in composite structures. When used as reinforced bar, it can significantly improve the ultimate bearing capacity of the bending components in timber structures. Bamboo-steel composites or bamboo rein- 
forced concrete can reduce the mass of the structures while maintaining their high bearing capacity.

- Bamboo structure has good seismic and fire resistance. Bamboo structure has good integrity, which is beneficial for the dissipation of seismic forces, and can realize the seismic target: the structure does not damage in small earthquakes nor collapse in violent earthquakes. The use of gypsum board and rock wool in GLB walls can effectively prevent the spread of fire and the conduction of high temperature.

- GLB has a small thermal conductivity; the good thermal performance enables bamboo structures to achieve a decrease of $65 \%$ energy consumption in cold regions.

- If the design and construction experience of high-rise wooden structures can be fully learnt to improve the efficiency of land use, the development of bamboo structures is a good choice for many developing countries rich in bamboo resources to ease economic development and environmental protection.

\section{Conflicts of Interest}

The authors declare no conflicts of interest regarding the publication of this paper.

\section{References}

[1] Bonilla, S.H., Guarnetti, R.L., Almeida, C.M.V.B. and Giannetti, B.F. (2010) Sustainability Assessment of a Giant Bamboo Plantation in Brazil: Exploring the Influence of Labor, Time, and Space. Journal of Cleaner Production, 18, 83-91. https://doi.org/10.1016/j.jclepro.2009.07.012

[2] Lee, A.W.C., Bai, X. and Peralta, P.N. (1994) Selected Physical Properties of Giant Timber Bamboo Grown in South Carolina. Forest Products Journal, 44, 40-46.

[3] Rittironk, S. and Elnieiri, M. (2007) Investigating Laminated Bamboo Lumber as an Alternate to Wood Lumber in Residential Construction in the United States. UK. https://doi.org/10.1201/9780203888926.ch9

[4] van der Lugt, P., van den Dobbelsteen, A.A.J.F. and Janssen, J.J.A. (2006) An Environmental, Economic, and Practical Assessment of Bamboo as a Building Material for Supporting Structures. Construction and Building Materials, 20, 648-656. https://doi.org/10.1016/j.conbuildmat.2005.02.023

[5] Li, X.Z., Zhong, Y. and Ren, H.Q. (2011) Development Prospect of Modern Bamboo Construction in China. Wood Processing Machinery, 22, 44-47. (In Chinese)

[6] Lee, P.H., Odllin, M. and Yin, H.M. (2014) Development of a Hollow Cylinder Test for the Elastic Modulus Distribution and the Ultimate Strength of Bamboo. Construction and Building Materials, 51, 235-243. https://doi.org/10.1016/j.conbuildmat.2013.10.051

[7] Dang, F.N., Liu, H.W. and Wang, X.W. (2013) Application of Bamboo as Tensile Reinforcement to Strengthening of Embankment of Soft Soils. Chinese Journal of Geotechnical Engineering, 35, 44-48. (In Chinese)

[8] Sheng, B.L., Zhou, A.P., Huang, D.S. and Huang, Z. (2015) Uniaxial Strength and Constitutive Law of Parallel Strand Bamboo. Journal of Nanjing Forestry University 
(Natural Science Edition), 39, 123-128. (In Chinese)

[9] Sharma, B., Gatóo, A., Bock, M. and Ramage, M. (2015) Engineered Bamboo for Structural Applications. Construction and Building Materials, 81, 66-73. https://doi.org/10.1016/j.conbuildmat.2015.01.077

[10] Yang, R.Z. (2013) Research on Material Properties of Glubam and Its Application. M.Sc. THESIS, Hunan University, Changsha. (In Chinese)

[11] Xiao, Y., Chen, G., Shan, B., Yang, R.Z. and She, L.Y. (2010) Research and Applicant of Lightweight Glue-Laminated Bamboo Frame Structure. Journal of Building Structure, 31, 195-203. (In Chinese)

[12] Xiao, Y. and Li, J. (2015) The State of the Art of Bamboo Structures. Industry Construction, 45, 1-6. (In Chinese)

[13] Wu, Y. and Xiao, Y. (2018) Steel and Glubam Hybrid Space Truss. Engineering Structures, 171, 140-153. https://doi.org/10.1016/j.engstruct.2018.05.086

[14] Ghavami, K. (2005) Bamboo as Reinforcement in Structural Concrete Elements. Cement and Concrete Composites, 27, 637-649. https://doi.org/10.1016/j.cemconcomp.2004.06.002

[15] Xiao, Y., Asce, M., Zhou, Q. and Shan, B. (2010) Design and Construction of Modern Bamboo Bridges. Journal of Bridge Engineering, 15, 533-541. https://doi.org/10.1061/(ASCE)BE.1943-5592.0000089

[16] Wei, Y., Lv, Q.F., Zhang, Q.S., Yu, Y.Z. and Lv, Z.T. (2009) Design and Construction of Modern Bamboo Anti-seismic Living Room. Construction Technology, 38, 52-54. (In Chinese)

[17] Zhou, Q., She, L.Y., Xiao, Y., Shan, B., Huo, J.S., Ma, J. and Yang, R.Z. (2011) Fire-Resistance Simulation and Test of Prefabricated Bamboo House. Journal of Building Structure, 32, 60-66. (In Chinese)

[18] American Forest, and Paper Association (AFPA) (2012) National Design Specification for Wood Construction. USA.

[19] GB50005-2003 (2012) Code for Design of Timber Structures. China. (In Chinese)

[20] EN 1995 (Eurocode 5) (2004) Design of Timber Structures. Brussel.

[21] Castanet, E., Li, Q.X., Ludovic, F., Dumée, L.F., Garvey, C., Rajkhowa, R., Zhang, J., Rolfe, B. and Magniez, K. (2016) Structure-Property Relationships of Elementary Bamboo Fibers. Cellulose, 23, 3521-3534. https://doi.org/10.1007/s10570-016-1078-8

[22] Scurlock, J.M.O., Dayton, D.C. and Hames, B. (2000) Bamboo: An Overlooked Biomass Resource? Biomass \& Bioenergy, 19, 229-244. https://doi.org/10.1016/S0961-9534(00)00038-6

[23] Xiao, J.Z., Li, W.G., Fan, Y.H. and Huang, X. (2012) An Overview of Study on Recycled Aggregate Concrete in China (1996-2011). Construction and Building Materials, 31, 364-383. https://doi.org/10.1016/j.conbuildmat.2011.12.074

[24] Yu, D.W., Tan, H.W. and Ruan, Y.J. (2011) A Future Bamboo-Structure Residential Building Prototype in China: Life Cycle Assessment of Energy Use and Carbon Emission. Energy and Buildings, 43, 2638-2646. https://doi.org/10.1016/j.enbuild.2011.06.013

[25] Naresworo, N.N.A. (2001) Development of Structural Composite Products Made from Bamboo II: Fundamental Properties of Laminated Bamboo Lumber. Journal of Wood Science, 47, 237-242. https://doi.org/10.1007/BF01171228

[26] Anwar, U.M.K., Paridah, M.T., Hamdan, H., Sapuan, S.M. and Bakar, E.S. (2009) Effect of Curing Time on Physical and Mechanical Properties of Phenolic-Treated 
Bamboo Strips. Industrial Crops and Products, 29, 214-219. https://doi.org/10.1016/j.indcrop.2008.05.003

[27] Li, Z., Yang, G.S., Zhou, Q., Shan, B. and Xiao, Y. (2019) Bending Performance of Gluban Beam Made with Difference Processes. Advances in Structural Engineering, 22, 535-546. https://doi.org/10.1177/1369433218794327

[28] Lo, T.Y., Cui, H.Z. and Leung, H.C. (2004) The Effect of Fiber Density on Strength Capacity of Bamboo. Materials Letters, 58, 2595-2598. https://doi.org/10.1016/j.matlet.2004.03.029

[29] Askarinejad, S., Kotowski, P., Youssefian, S. and Rahbar, N. (2016) Fracture and Mixed-Mode Resistance Curve Behavior of Bamboo. Mechanics Research Communications, 78, 79-85. https://doi.org/10.1016/j.mechrescom.2016.02.001

[30] Pan, Y., Li, J.J., Li, L.J., Qin, N. and Tang, L.N. (2011) Application of the Modern Bamboo in Building Structure. Journal of Civil, Architectural \& Environmental Engineering, 33, 115-118. (In Chinese)

[31] Zhang, J.Z., Ren, H.Q., Zhong, Y. and Zhao, R.J. (2012) Analysis of Compressive and Tensile Mechanical Properties, of Recombinant Bamboo. Journal of Nanjing Forestry University (Natural Science Edition), 36, 107-111. (In Chinese)

[32] Lee, A.W.C., Bai, X. and Bangi, A.P. (1997) Flexural Properties of Bamboo-Reinforced Southern Pine OSB Beams. Forest Products Journal, 47, 74-78.

[33] Chen, G.H., Liu, Q., Zeng, X.Y., Zhou, Q.Z., Hong, H.K. and Liu, F.Z. (2015) Study on Reconstituted Bamboo Board Strengthening Laminated Wood Beam. Shanxi Arch, 41, 53-54. (In Chinese)

[34] Li, Y.S., Shen, H.Y., Shan, W. and Han, T.S. (2012) Flexural Behavior of Lightweight Bamboo-Steel Composite Slabs. Thin-Walled Structures, 53, 83-90.

https://doi.org/10.1016/j.tws.2012.01.001

[35] Li, Y.S., Zhang, J.L., Zhang, X.H., Wen, Y. and Guo, J. (2015) Study on Bond Stress and Bond Slip of Bamboo-Steel Interface under Static Load. Journal of Building Structure, 36, 114-123. (In Chinese)

[36] Zhang, Z.W., Li, Y.S. and Liu, R. (2016) Failure Behavior of Adhesive Bonded Interface between Steel and Bamboo Plywood. Journal of Adhesion Science and Technology, 30, 2081-2099. https://doi.org/10.1080/01694243.2016.1173390

[37] Lopez, O.H. (2003) Bamboo-The Gift of the Gods. Journal of Bamboo and Rattan, 2, 297-298. https://doi.org/10.1163/156915903322555586

[38] Rahman, M.M., Rashid, M.H., Hossain, M.A., Hasan, M.T. and Hasan, M.K. (2011) Performance Evaluation of Bamboo Reinforced Concrete Beam. International Journal of Engineering and Technology, 11, 113-118.

[39] Indra, I.G. (1982) Bamboo as Expedient Reinforcement for Concrete Beams. M.Sc. Thesis, University of Ottawa, Ottawa.

[40] Khare, L. (2005) Performance Evaluation of Bamboo Reinforced Concrete Beams. M.Sc. Thesis, University of Texas at Arlington.

[41] Li, D.H. (1986) Bamboo Reinforced Concrete Components Are Not Suitable for Load-Bearing Structures. Journal of Building Technology, 4, 52-53. (In Chinese)

[42] Hu, S.L. (1956) Preliminary Study on Bamboo Reinforced Concrete Slab. Journal of Harbin Institute of Technology, 10, 3-24. (In Chinese)

[43] Ma, L.F. and Ma, N.X. (1997) Study on the Variation of Moso Bamboo. Forest Sciences, 33, 356-364. (In Chinese)

[44] Ghavami, K. (1995) Ultimate Load Behaviour of Bamboo-Reinforced Lightweight Concrete Beams. Cement and Concrete Composites, 17, 281-288. 
https://doi.org/10.1016/0958-9465(95)00018-8

[45] Terai, M. and Minami, K. (2011) Fracture Behavior and Mechanical Properties of Bamboo Reinforced Concrete Members. Procedia Engineering, 10, 2967-2972. https://doi.org/10.1016/j.proeng.2011.04.492

[46] Budi, A.S., Rismunarsi, E. and Sunaryo. (2015) Flexural Capacity of Bamboo Strip Notched Reinforced Concrete Beams. Applied Mechanics and Materials, 845, 208-213. https://doi.org/10.4028/www.scientific.net/AMM.845.208

[47] Archila, H., Kaminski, S., Trujillo, D., Escamilla, E.Z. and Harries, K.A. (2018) Bamboo Reinforced Concrete: A Critical Review. Materials and Structures, 51, 102. https://doi.org/10.1617/s11527-018-1228-6

[48] Saikia, P., Dutta, D., Kalita, D., Kalita, D., Jayanta, J.B. and Goswami, T. (2015) Improvement of Mechano-Chemical Properties of Bamboo by Bio-Chemical Treatment. Construction and Building Materials, 101, 1031-1036. https://doi.org/10.1016/j.conbuildmat.2015.10.106

[49] Zhang, L.S., Qin, D.C., Ren, H.L. and Jin, X.B. (2013) Effects of Preservative Post-Treatment of the Bamboo Glulam on Its Durability. China Forestry Products Industry, 40, 55-57. (In Chinese)

[50] Shan, B., Zhou, Q. and Xiao, Y. (2010) Research and Construction of Modern Bamboo Pedestrian Bridges. Building Structure, 40, 92-96. (In Chinese)

[51] Xiao, Y., Zhou, Q. and Shan, B. (2010) Design and Construction of Modern Bamboo Bridges. Journal of Bridge Engineering, 15, 533-541. https://doi.org/10.1061/(ASCE)BE.1943-5592.0000089

[52] Arijit, S., Asce, A.M., Daniel, W. and Mlasko, S. (2014) Structural Performance of Glued Lamiated Bamboo Beams. Journal of Structural Engineering, 140, AArticle ID: 04013021. https://doi.org/10.1061/(ASCE)ST.1943-541X.0000807

[53] Xiao, Y., Feng, L., Lü, X.H., She, L.Y. and Shen, Y.L. (2015) Experimental Study of Glubam Columns under Axial Loads. Industrial Construction, 45, 13-17. (In Chinese)

[54] Yang, Y.F. and He, L.P. (2008) Elementary Research on Construction Technology of Glued Lamiated Bamboo Wood Building. Huazhong Architecture, 26, 88-89, 96. (In Chinese)

[55] Xiao, Y., She, L.Y., Shan, B., Zhou, Q., Chen, G. and Yang, R.Z. (2009) Application of Bamboo Structure to Reconstruction after Wenchuan Earthquake. Journal of Natural Disasters, 18, 14-18. (In Chinese) https://doi.org/10.2749/222137809796078333

[56] Folz, B. (2004) Seismic Analysis of Wood Frame Structures. I: Model Formulation, and II: Model Implementation and Verification. Journal of Structural Engineering, 130, 1353-1370. https://doi.org/10.1061/(ASCE)0733-9445(2004)130:9(1361)

[57] Li, Y. (2007) Reliability of Wood Frame Residential Construction Subjected to Earthquakes. Structural Safety, 29, 294-307. https://doi.org/10.1016/j.strusafe.2006.07.012

[58] Xiao, Y., Ma, J., Shan, B., Chen, G. and She, L.Y. (2012) Experimental Research on fire Safety of Lightweight Bamboo Frame Buildings. Building Structure, 42, 165-169. (In Chinese)

[59] Xiao, Y. and Ma, J. (2012) Fire Simulation Test and Analysis of Laminated Bamboo Frame Building. Construction and Building Materials, 34, 257-266. https://doi.org/10.1016/j.conbuildmat.2012.02.077

[60] Wang, J.S., Demartino, Xiao, Y. and Li, Y.Y. (2018) Thermal Insulation Perfor- 
mance of Bamboo- and Wood-Based Shear Walls in Light-Frame Buildings. Energy Buildings, 168, 167-179. https://doi.org/10.1016/j.enbuild.2018.03.017

[61] Tian, Y.L., Lu, J.M. and Jiang, S.X. (2012) Study on the Thermal Performance of External Wall of Bamboo Structure. Journal of Nanjing Forestry University (Natural Science Edition), 36, 96-100. (In Chinese)

[62] Xiao, S.B., Li, N.P., Li, J., Xiao, Y. and Shan, B. (2008) Measurement and Research on Indoor Air Quality of Bamboo Structure Houses. Journal of Safety and Environment, 8, 87-90. (In Chinese) 